\title{
Parametric Effect of Distillery Effluent as Substrate in Microbial Fuel Cell for Power Generation
}

\author{
Mohammad Siddique', Mohammmad Najam Khan¹, Abdul Sattar Jatoi², Shaheen Aziz ${ }^{3}$, Sohail Ahmed \\ Soomro ${ }^{3}$ \\ 1Department of Chemical Engineering, Faculty of Engineering and Architecture, Balochistan University of Information \\ Technology, Engineering and Management Sciences, Quetta, Pakistan, ${ }^{2}$ Department of Chemical Engineering Dawood \\ University of Engineering \& Technology, Karachi, Pakistan, ${ }^{3}$ Department of Chemical Engineering, Mehran University of \\ Engineering \& Technology, Jamshoro, Pakistan
}

\begin{abstract}
Depletion of fossil fuel increased direction towards renewalable energy sources. Microbial Fuel Cell substitute technology for converting waste water from industry effluent as well meet the requirement for environmental problem. Study was made to treat the distillery effluent as substrate in mfc for bio-energy considering effect of oxygen flow rate, $\mathrm{pH}$ and substrate concentration. Different organic load were used in mfc for power generation and different oxygen flowrate for oxidation of proton coming from anode chamber effect of $\mathrm{pH}$ also keep consideration regading microbial growth of saccharomyces as a biocatalyst. The maximum power generation were observed at optimized condition of oxygen flow rate $250 \mathrm{rpm}$, pH6 and substrate $60 \%$ (in form of organic load) at $0.9114 \mathrm{~mW}$ and current density $82.48 \mathrm{~mA} / \mathrm{m}^{2}$.
\end{abstract}

Keywords: Distillery; Effluent; Substrate; Power Generation; MFC

Corresponding author's email: siddiqnasar786@gmail.com

\section{INTRODUCTION}

The growing demand for energy, depletion of fossil fuels and increasing concerns of environmental issues have challenged researchers to develop new technological processes to generate clean and sustainable energy mainly through the utilization of renewable energy sources (Cai et al., 2013; Jatoi et al., 2016c; Jatoi et al., 2018; Liu et al., 2014; Logan et al., 2006). Recently, microbial fuel cell (MFC) technology has emerged as a promising sustainable technology to meet increasing energy demand that can utilize organic materials as a fuel (Pant et al., 2010; Yusoff et al., 2013) . MFCs are bio-electrochemical devices capable of converting biochemical energy into electricalenergy through the catalytic reaction of microorganisms (Yusoff et al., 2013). MFCs have remarkable electron-donor versatility as the microbes usewastewater as substrates to generate electricity and simultaneously accomplish wastewater treatment (Jatoi et al., 2016a; Jatoi et al., 2016b; Lu et al., 2009; Oh and Logan, 2005; Pant et al., 2010; Parkash et al., 2015; Soomro et al., 2016). Production of unmanageable quantity of sewage sludge from wastewater treatment plants is the major issue in terms of capitaland environmental burden. This costs $60 \%$ of the total plant capital cost, and its disposal has become problematic due to stringent sludge disposal laws (Canales et al., 1994; Pilli et al., 2011; Xiao et al., 2013). MFC technology provides new opportunities for the sustainable wastewater treatment by converting waste into energy, which may offset the operational costs of wastewater treatment plant (Lu et al., 2009). High concentrations of organic matter, mainly protein and carbohydrate can be found in sewage sludge (Wang et al., 2006; Xiao et al., 2013). Wang et al. (2006) reported the total protein and carbohydrate in sludge to be $12,036 \mathrm{mg} / \mathrm{L}$ and $2109 \mathrm{mg} / \mathrm{L}$ respectively. However, it is known that generation of power during the MFC process might be influenced by the efficient degradation of biomass in MFCs (Bougrier et al., 2008). In this study distillery effluent used as substrate in mfc for power generation.

\section{MATERIALS AND METHODS Microorganism}

Yeast S.cerevisiae M-9 (Shah et al., 2010) were purchase from local market with analytical grade. 
Inoculums of yeast were preperad from following composition with $250 \mathrm{ml}$ medium which contained in g.l-1: glucose, 10; $\left(\mathrm{NH}^{4}\right)^{2} \mathrm{HPO}^{4}, 0.64$, and yeast extract 2.5; at $\mathrm{pH} 5.5$ and incubated for $18 \mathrm{~h}$ on an orbital shaker at $150 \mathrm{rpm}$ at $30^{\circ} \mathrm{C}$.

Distillery effluent characteristic

Distillery effluent were collected from al abbas distillery plant and analyzed given in table 1.

Table 1: Characteristic of distillery waste water

\begin{tabular}{|c|c|}
\hline Characteristic & Average value \\
\hline $\mathrm{pH}$ & 3.99 \\
\hline Colour & Dark Brown \\
\hline BOD3 $(\mathrm{mg} / \mathrm{L})$ & 36666 \\
\hline COD $(\mathrm{mg} / \mathrm{L})$ & 89833 \\
\hline Total Solids $(\mathrm{mg} / \mathrm{L})$ & 74033 \\
\hline Dissolved Solids (mg/L) & 59733 \\
\hline Chlorides $(\mathrm{mg} / \mathrm{L})$ & 6933 \\
\hline Conductivity $(\mathrm{mS} / \mathrm{cm})$ & 20.2 \\
\hline
\end{tabular}

\section{Configuration of MFC}

The H-shaped MFCs were fabricated with two polycarbonate bottles $(500 \mathrm{~mL})$ as chambers and a PVC pipe $(5 \mathrm{~cm} \times 1 \mathrm{~cm})$ for preparing a salt bridge. The slat bridges were prepared by filling boiled sodium chloride $(10 \%)$ solution containing $5 \%$ agar. The salt bridges were fixed to the bottles with the aid of epoxy adhesive. The electrodes were inserted into respective chambers while circuit connections were set with the copper wires fixed into the drilled holes of the electrodes and sealed with epoxy resin to avoid corrosion of copper wire (Jatoi et al., 2018). The fabricated MFCs were sterilized with Ethanol (70\%) and irradiated with UV for $15 \mathrm{~min}$. The electrolytes were added up to the brim of the respective chambers to maintained air free conditions.

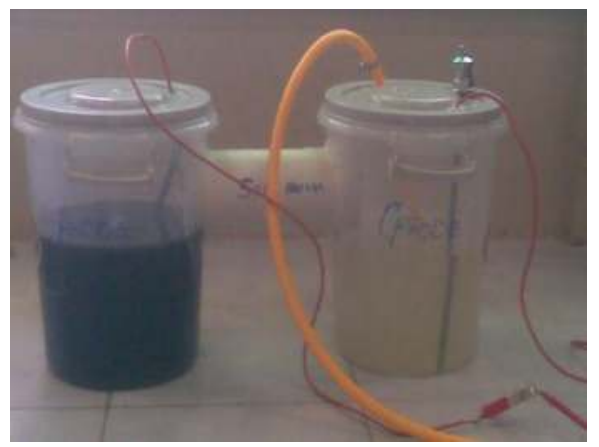

Figure 1: Typical MFC Camera View 


\section{Preparation of anode and cathode chamber}

Two chamber were prepared with carbon electrodes, aerobic condition were maintained in cathode and anaerobic in anode. The air fish pump were used for oxidation of proton coming from anode to cathode chamber for water formation. Under different ph of anode chamber were maintained for power generation to make best condition for microbial growth in MFC. Cathode chamber were maintained with aerobic condition for promoting proton coming from anode chamber for oxidation.

\section{Preperation of salt bridge}

Salt bridge was prepared from different salt such are $\mathrm{NaCL} \mathrm{KCL}$ and agar salt for making gel like membrane for transferring of proton from anode to cathode chamber.

\section{Running of MFC}

Distillery effluent were added in anode chamber under anaerobic condition with inoculums prepared for growth of saccharomyces servisae as biocatalyst for utilizing organic matter for bio-generation of electricity. Cathode chamber were maintained by salt water under aerobic condition with addition of oxygen by fish pump to promote oxidation of proton coming from anode chamber.

Electron transferred occur with installing carobon electrode through external resistance.

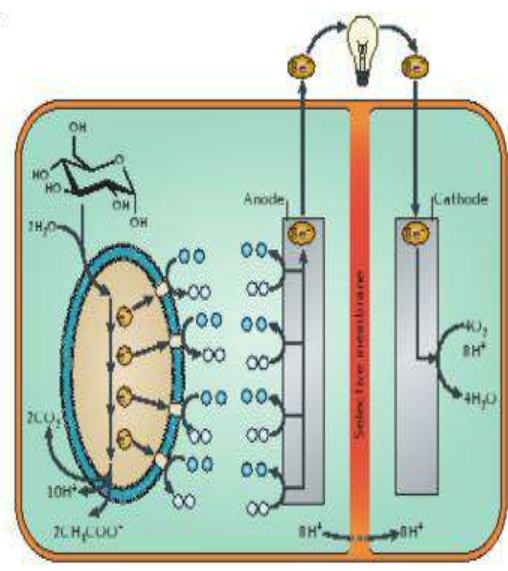

Figure 2: Basic operation of MFC

\section{Analysis of MFC}

In MFC different parameter were analysed during experimental work on it .

pH

$\mathrm{pH}$ were analysed using $\mathrm{pH}$ meter to set the desired condition for microbial growth, because if the $\mathrm{pH}$ increases above the 8.5 and below the 6 there will be effect on microbial growth in MFC.

\section{Oxygen flowrate}

Oxygen flow rate were analysed with the help of flow meter to know about the oxygen enter in the MFC cathodic chamber, because we make cathodic chmber aerobic condition .

\section{Voltage Generated}

Current was analysed by using multimeter, different concentration and $\mathrm{pH}$ were used to saw the behavior of the system , at what concentration and $\mathrm{pH}$ had maximum output of power generation. Voltage was continuously measured by a multimeter with a data acquisition system. Current (I) was calculated from the voltage $(\mathrm{V})$ by $\mathrm{I}=\mathrm{V} / \mathrm{Re}$, where $\mathrm{Re}$ is the external resistance. Power $(\mathrm{P})$ was calculated as $\mathrm{P}=\mathrm{IV}$ (Wei et al., 2012).

\section{RESULTS AND DISCUSSION}

During running of MFC different process parameter effect on electrcity generation. Different parameter of mfc were tested and analysed. Voltage generation from MFC were measured by volt meter and current, current density, power, power density were calculated by following relation.

$\mathrm{P}=\mathrm{VI}$

Power density $=$ power $/$ area of anode 
Current density = current generated/ area of anode

In table 02 current and power genartion were listed with different oxygen flowrate and ph ranges the maximum electrcity were observed at $250 \mathrm{ml} / \mathrm{min}$ of oxygen flowrate $0.98 \mathrm{~mA}$ and for ph the maximum generation of bioenergy at 6 with voltage generation 0.82 Volts.

Table 2: Current, Voltage, Power, Power Density and Current Density at various parameter

\begin{tabular}{|c|c|c|c|c|c|c|c|c|c|c|c|}
\hline \multirow{2}{*}{ Parameter } & \multicolumn{4}{|c|}{ Oxygenflowrate (ml/min) } & \multicolumn{4}{|c|}{$\mathrm{pH}$ value } & \multicolumn{3}{|c|}{ Substrate $\% w / v$} \\
\hline & 100 & 150 & 200 & 250 & 4.5 & 5 & 5.5 & 6 & 20 & 40 & 60 \\
\hline $\begin{array}{l}\text { Current } \\
(\mathrm{mA})\end{array}$ & 0.81 & 0.89 & 0.94 & 0.98 & 0.79 & 0.83 & 0.86 & 0.89 & 0.75 & 0.79 & 0.83 \\
\hline $\begin{array}{l}\text { Voltage } \\
\text { (volts) }\end{array}$ & 0.77 & 0.86 & 0.95 & 0.97 & 0.75 & 0.79 & 0.82 & 0.85 & 0.72 & 0.74 & 0.77 \\
\hline $\begin{array}{l}\text { Power } \\
(\mathrm{mW})\end{array}$ & $\begin{array}{c}0.62 \\
37\end{array}$ & 0.7654 & 0.893 & $\begin{array}{c}0.911 \\
4\end{array}$ & $\begin{array}{c}0.59 \\
25\end{array}$ & 0.6557 & $\begin{array}{c}0.70 \\
52\end{array}$ & $\begin{array}{c}0.75 \\
65\end{array}$ & 0.54 & $\begin{array}{c}0.58 \\
46\end{array}$ & $\begin{array}{c}0.639 \\
1\end{array}$ \\
\hline $\begin{array}{c}\text { Power } \\
\text { density } \\
(\mathrm{mW} / \mathrm{m} 2)\end{array}$ & $\begin{array}{c}50.4 \\
3\end{array}$ & 61.53 & 71.98 & 78.42 & $\begin{array}{c}49.3 \\
75\end{array}$ & $\begin{array}{c}54.641 \\
67\end{array}$ & $\begin{array}{l}58.7 \\
667\end{array}$ & $\begin{array}{l}63.0 \\
4167\end{array}$ & 45 & $\begin{array}{l}48.7 \\
1667\end{array}$ & $\begin{array}{c}53.25 \\
833\end{array}$ \\
\hline $\begin{array}{l}\text { Current } \\
\text { density } \\
(\mathrm{mA} / \mathrm{m} 2)\end{array}$ & $\begin{array}{c}67.2 \\
9\end{array}$ & 73.98 & 78.97 & 82.48 & $\begin{array}{l}65.8 \\
333\end{array}$ & $\begin{array}{c}69.166 \\
7\end{array}$ & $\begin{array}{c}71.6 \\
7\end{array}$ & $\begin{array}{c}74.1 \\
67\end{array}$ & 62.5 & $\begin{array}{c}65.8 \\
33\end{array}$ & $\begin{array}{c}69.16 \\
6\end{array}$ \\
\hline
\end{tabular}

\section{Effect of oxygen flowrate on power generation}

In mfc operation were successful with addition of air in proper into cathode chamber for oxidation proton coming through salt bridge from anode chamber. Different ranges of oxygen were under investigation for promoting energy generation from distillery effluent. From $100-250 \mathrm{ml} / \mathrm{min}$ of air flowrate tested and analyzed the maximum voltage generated at $250 \mathrm{ml} / \mathrm{min}$ with $0.98 \mathrm{v} / \mathrm{l}$. in fig 03 it highlights after 56 hour the line in decreasing way due to the changing in dissolved oxygen, because during running of mfc different parameter effect regarding dissolve oxygen becuas at that time temperature of cathode chamber increasing it decease the voltage generation.

\section{Effect of $\mathrm{pH}$ on power generation}

Acidic and basic nature had importance regarding microbial growth in MFC, regaring biocatalyst saccharomyces specii for their nature it active in acidic nature of the solution and could serviveph ranges from 4-6.5. highlighting this problem effect of ph under consideration for maximing the activity of biocatalyst. For power generation from distillery effluent the maximum power production observed at $\mathrm{pH} 6$ about $0.85 \mathrm{v} / \mathrm{l}$ as shown in figure 04 . It colud helpful for meeting environmental condition for generating power from distillery effluent and decrease the percentage of waste water promoting renewlable energy.pH is a significant factor that affecting the activity of microbes. Growth and development of microbe's maximum at optimum $\mathrm{pH}$. The experiments show that at $\mathrm{pH} 6$ and below, activities of microbes minimum when compared with the result recorded at higher $\mathrm{pH}$. This is by the neutralization of proteins or active sites under acidity. These results demonstrate that there is also impact of $\mathrm{pH}$ on voltage Generation (Shah et al., 2010). 
Parametric Effect of Distillery Effluent as Substrate in Microbial Fuel Cell for Power Generation

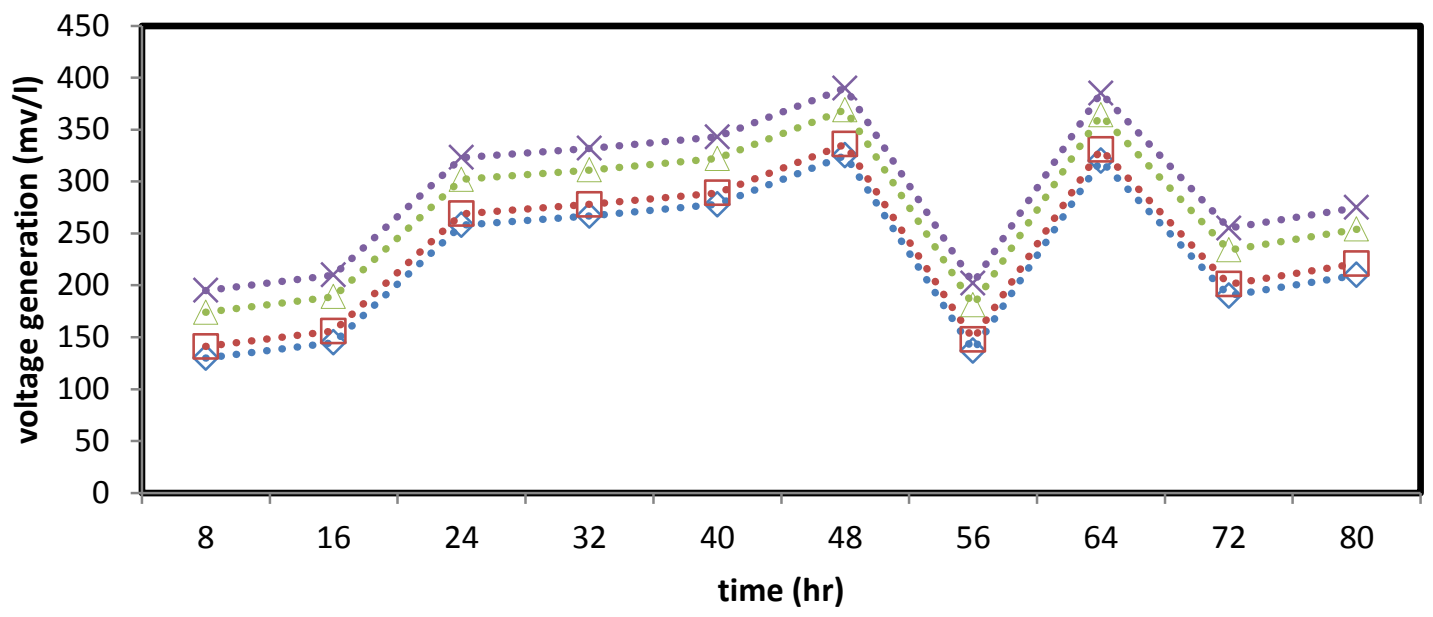

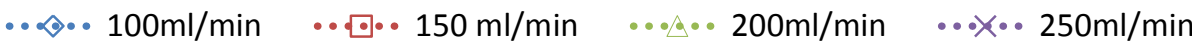

Figure 3: Effect of oxygen flow rate on power generation from MFC

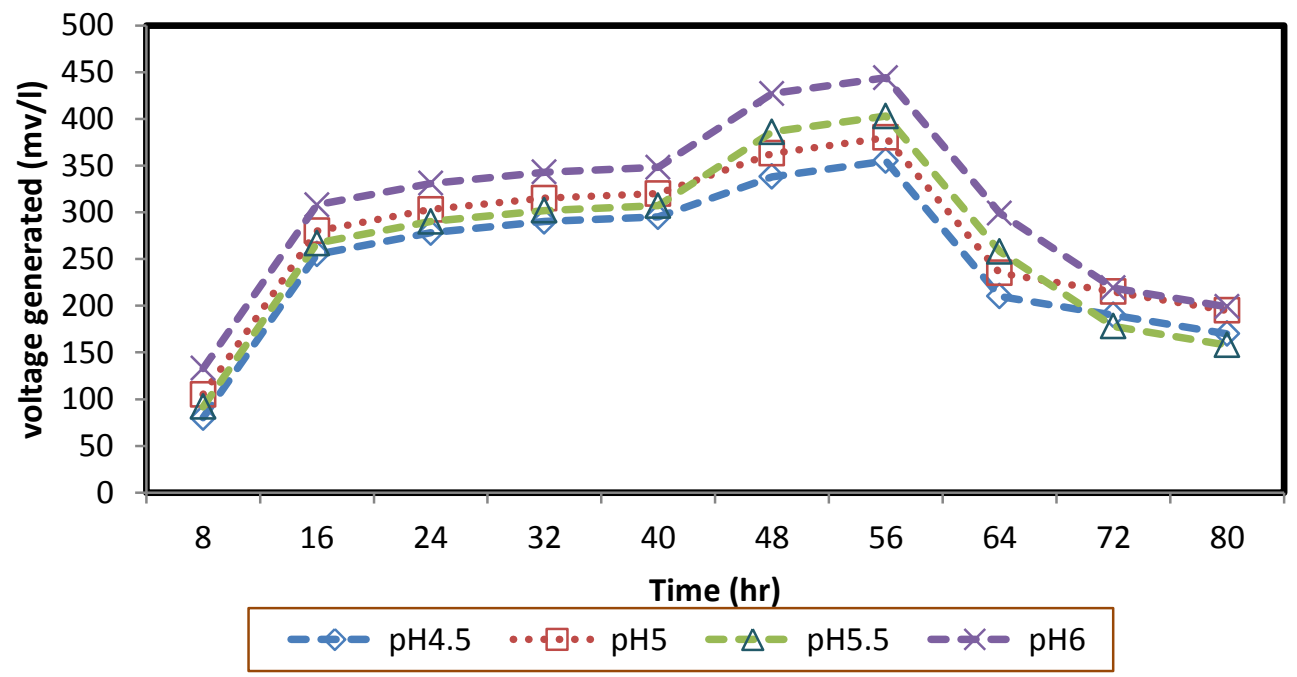

Figure 4: Effect of $\mathrm{pH}$ on power generation from MF

\section{Effect of substrate concentration}

Different Substrate concentration were tested in MFC for power generation by utilizing distillery effluent as substrate. From $20-60 \%$ w/v of substrate were used in MFC for identifying the range where maximum power production maximum from fig 05 observation suggest when concentration of distillery effluent increases upto $60 \%$ power generation maximum, this could be due to the decreasing organic compound present in distillery effluent and microbial activity could inhbit by changing the concentration of substrate and maximum power generation observed when substrate concentration $60 \%$ about $0.82 \mathrm{~mA}$. 


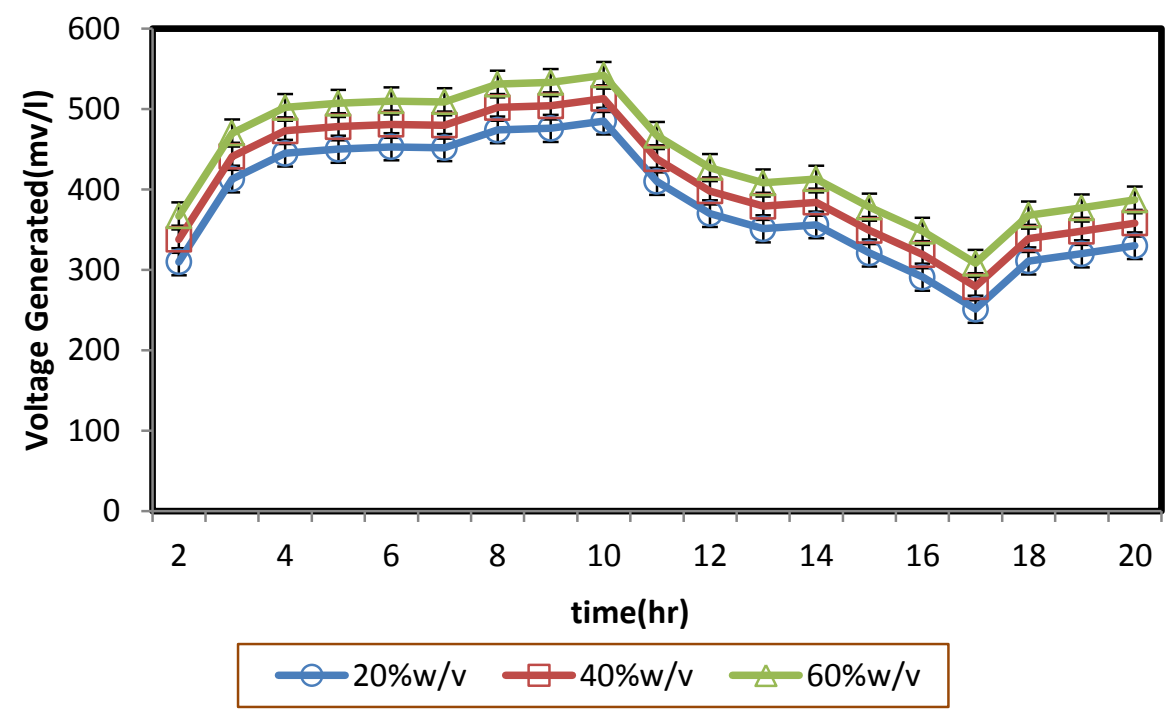

Figure 5: Effect of Substrate Concentration on power generation from MFC

\section{CONCLUSION}

The double chamber MFC using Saccharomyces cerevisiae with various substrate concentrations and oxygen flowrate for the performance and process optimized. The suitable substrate concentration of distillery where maximum voltage $0.97 \mathrm{~V}$ and maximum current $0.98 \mathrm{~mA}$ is at $60 \% \mathrm{w} / \mathrm{v}$. Internal resistance resist the generation of voltages as a higher grade of polymerization of the gel, internal resistance build up inside the cell. The maximum power generation were optimized at $\mathrm{pH} 6,250 \mathrm{ml} / \mathrm{min}$ of oxygen flow rate and $60 \% \mathrm{w} / \mathrm{v}$ of distillery effluent gave maximum power generation $0.9114 \mathrm{~mW}$. It could be say that mfc could help to improve the utilization waste material into energy generation.

\section{REFERENCES}

- Bougrier C, Delgenes JP, Carrere H. (2008). Effects of thermal treatments on five different waste activated sludge samples solubilisation, physical properties and anaerobic digestion. Chemical Engineering Journal 139(2):236-244.

- Cai H, Wang J, Bu Y, Zhong Q. (2013). Treatment of carbon cloth anodes for improving power generation in a dual- chamber microbial fuel cell. Journal of Chemical Technology \& Biotechnology 88(4):623-628.

- Canales A, Pareilleux A, Rols JL, Huyard A. (1994). Decreased sludge production strategy for domestic wastewater treatment. Water Science and Technology 30(8):97-106.

- Jatoi AS, Mahar H, Aziz S, Siddique M, Memon F, Malik AA, Hussain S, Kakar E. (2016a). To Investigate the Optimized Conditions of Salt Bridge for Bio-Electricity Generation from Distillery Waste Water Using Microbial Fuel Cell. NUST Journal of Engineering Sciences 9(2):29-34.

- Jatoi AS, Mazari S, Baloch HA, Riaz S. (2016b). 256. Study to Investigate the Optimize Blending Ratio of Cow Dung Manure with Distillery Waste Water for Power Generation in Microbial Fuel Cell, 4th International Conference on Energy, Environment and Sustainable Development 2016 (EESD 2016)

- Jatoi AS, Siddique M, Mengal AN, Soomro SA, Aziz S. (2016c). Comparative Study of Different Biomass on Bio-electricity Generation Using Microbial Fuel Cell. Journal of Applied and Emerging Sciences 6(2):74-78. 
- Jatoi AS, Tunio MM, Riaz S, Abro R, Wajahat MH, Qureshi K, Shah A, Nizamuddin S, Mubarak NM. (2018). Utilization of Distillery Effluent as Substrate for Power Generation with Optimized Parametric Conditions using Microbial Fuel Cell. Eurasian Journal of Analytical Chemistry 13(5):1-8.

- Liu W, Mu W, Liu M, Zhang X, Cai H, Deng Y. (2014). Solar-induced direct biomass to electricity hybrid fuel cell using polyoxometalates as photocatalyst and charge carrier. Nature communications 5:1-8.

- Logan BE, Hamelers B, Rozendal R, Schröder U, Keller J, Freguia S, Aelterman P, Verstraete W, Rabaey K. (2006). Microbial fuel cells: methodology and technology. Environmental science \& technology 40(17):5181-5192.

- Lu N, Zhou SG, Zhuang L, Zhang JT, Ni JR. (2009). Electricity generation from starch processing wastewater using microbial fuel cell technology. Biochemical engineering journal 43(3):246-251.

- Oh S, Logan BE. (2005). Hydrogen and electricity production from a food processing wastewater using fermentation and microbial fuel cell technologies. Water research 39(19):4673-4682.

- Pant D, Van Bogaert G, Diels L, Vanbroekhoven K. (2010). A review of the substrates used in microbial fuel cells (MFCs) for sustainable energy production. Bioresource technology 101(6): 1533-1543.

- Parkash A, Aziz S, Abro M, Kousar A, Soomro SA, Jatoi AS. (2015). Impact of agarose concentrations on electricity generation using hostel sludge based duel chambered microbial fuel cell. Science International (Lahore) 27(2):1057-1061.

- Pilli S, Bhunia P, Yan S, LeBlanc R, Tyagi R, Surampalli R. (2011). Ultrasonic pretreatment of sludge: a review. Ultrasonics sonochemistry 18(1):1-18.

- Shah FA, Aziz S, Rajoka M. (2010). Ethanol production kinetics by a thermo-tolerant mutant of Saccharomyces cerevisiae from starch industry waste (Hydrol). Pakistan Journal of Analytical \& Environmental Chemistry 11(1):6-21.

- Soomro SA, Siddique M, Aftab A, Qaisrani ZN, Jatoi AS, Khan A, Khan G, Kakar E. (2016). Comparative Study of Coal and Biomass Co-Combustion with Coal Burning Separately Through Emissions Analysis. Pakistan Journal of Analytical \& Environmental Chemistry 17(1):18-22.

- Wang F, Lu S, Ji M. (2006). Components of released liquid from ultrasonic waste activated sludge disintegration. Ultrasonics sonochemistry 13(4):334-338.

- Wei L, Yuan Z, Cui M, Han H, Shen J. (2012). Study on electricity-generation characteristic of two-chambered microbial fuel cell in continuous flow mode. international journal of hydrogen energy 37(1):1067-1073.

- Xiao B, Yang F, Liu J. (2013). Evaluation of electricity production from alkaline pretreated sludge using two-chamber microbial fuel cell. Journal of hazardous materials 254:57-63.

- Yusoff MZM, Hu A, Feng C, Maeda T, Shirai Y, Hassan MA, Yu CP. (2013). Influence of pretreated activated sludge for electricity generation in microbial fuel cell application. Bioresource technology 145: 90-96. 